\title{
The Impact of Myths, Superstition and Harmful Cultural Beliefs against Albinism in Tanzania: A Human Rights Perspective
}

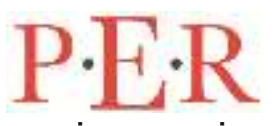

Pioneer in peer-reviewed, open access online law publications

Authors

Ines Kajiru

Isaack Nyimbi

Affiliation

University of Dodoma, Tanzania

Email

ikajiru@gmail.com

isaacknyimbi@hotmail.com

Date Submission

4 October 2019

Date Revised

28 July 2029

Date Accepted

28 July 2020

Date published

28 Augustus 2020

Editors F Dube \& AA Agbor

How to cite this article

Kajiru I and Nyimbi I "The Impact of Myths, Superstition and Harmful Cultural Beliefs against Albinism in Tanzania: A Human Rights

Perspective" PER / PELJ 2020(23) DOI http://dx.doi.org/10.17159/17273781/2020/v23i0a8793

Copyright

DOI http://dx.doi.org/10.17159/17273781/2020/v23i0a8793

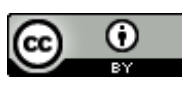

\begin{abstract}
It cannot be denied that myths and superstitions have endured through history and that people have been affected by them since the beginning of time. Superstitious beliefs and myths that result in the victimization of persons with albinism (PWA) are centuries old, are present in cultural attitudes and practised around the world. In Africa and in Tanzania in particular, PWAs have also been targeted because of harmful speculation and unfounded myths which place their lives at risk. As members of society PWA have human rights that need to be protected against any kind of violation, particularly against being killed, tortured and discriminated against. This article analyses various legal provisions that protect the rights of PWA as articulated in various UN covenants and conventions as well as regional treaties and national laws.
\end{abstract}

Secondary data are consulted to examine the extent of the erroneous beliefs which heavily fuel the persecution and killing of PWA. It is found that there are deep-seated myths, superstitions and harmful cultural beliefs the existence of which seems to pose a serious obstacle to the implementation of the law and the protection of the rights of PWA in Tanzania. The article recommends awareness-raising and education in general for Tanzanian society as an approach towards the protection of PWA.

\section{Keywords}

Myths; superstition; harmful cultural beliefs; albinism; human rights; Tanzania. 


\section{Introduction}

Superstitions and myths have endured through the course of history and have evolved from time to time. Most people, at some point in their lives, have encountered them. Myths and superstitions have been a crucial part of their cultures, relating to their methods of worshipping, being harbingers of good or bad luck, predicting of the future, healing, and preventing disease and accidents. ${ }^{1}$ Every society has at some time or other possessed within itself myths and superstitions. They can be found in different societies all over the world, but some may be limited to one continent, region, country, village, ward, clan/tribe/ethnicity/race, family and so on, and sometimes to one social group. ${ }^{2}$ African history discloses the existence of numerous myths that can be distilled from stories. One of these involves albinism. Like many other things in Africa's diverse cultures, albinism is surrounded by many harmful cultural beliefs and superstitions. This has people regard PWA with suspicion and fear. Many societies consider PWA evil, mysterious, and often, incapable of doing things that other human beings with no albinism can do.

Myths and superstitions against PWA may have their origins in Neolithic Eastern European cultures where, at that time, death was personified as "a pallid woman with light hair". ${ }^{3}$ Noteworthy is the fact that in European tradition the fear of vampires and other renowned "undead" apparitions with a "deathly pallor" could also have played a role in fuelling discrimination against PWA. ${ }^{4}$ According to the National Organization for Albinism and Hypopigmentation (NOAH), which exists in the United States and Canada and is a non-profit advocacy group for PWAs, sixty-eight films that portray or attribute negative characteristics to PWA have been released. ${ }^{5}$ For example, a film based on Wells' 1897 science-fiction novel portrays the supernatural powers of "The Invisible Man". ${ }^{6}$ This fictional character uses a

\footnotetext{
* Ines Kajiru. LLB LLM (Mzumbe Univ, Tanzania) PhD (UKZN, South Africa). Lecturer Department of Law, College of Business Studies and Law, University of Dodoma, Tanzania. Email: ikajiru@gmail.com. ORCiD: https://orcid.org/0000-0002-1919-1148.

** Isaack Nyimbi. LLB (Ruaha Univ College, Tanzania), LLM (International University College of Turin, Italy). Assistant Lecturer, Department of Law, College of Business Studies and Law, University of Dodoma, Tanzania. Email: isaacknyimbi@hotmail.com. ORCiD: https://orcid.org/0000-0002-5378-9661.

Agazue Role of Culture.

Agazue Role of Culture.

OHCHR 2019 https://uganda.ohchr.org/Content/publications/Albinism_Analysis_ eport_2019.pdf.

$4 \quad \mathrm{OHCHR} 2019$ https://uganda.ohchr.org/Content/publications/Albinism_Analysis_ Report_2019.pdf.

5 Schiappa Beyond Representational Correctness 6.

$6 \quad$ Schiappa Beyond Representational Correctness 6.
} 
scientific invention which makes him capable of becoming invisible. Nevertheless, the film sent a message to superstitious societies that such "magic" was possible because the man who performed it had no pigment. ${ }^{7}$ What contributed to the powerful influence of this film was that, subsequent to his experimentation, "The Invisible Man" eventually became totally deranged, which identified him as a "desperado albino". 8 This alienated him from society and people were no longer interested in supporting him even in normal daily activities. ${ }^{9}$ The alienation became extreme when people thought that even the law no longer applied to the "Invisible Man" because he could not be arrested and brought to trial. ${ }^{10} \mathrm{He}$ therefore plotted a "reign of terror", dreaming of fathering a novel master race of invisible men. ${ }^{11}$

It is indisputable that people in Africa and in particular in Tanzania have different beliefs about people with albinism. ${ }^{12}$ In Tanzania these beliefs vary from one tribe and community to another. ${ }^{13}$ For example, some of the tribes in Tanzania believe that persons with albinism are not human beings but ghosts. ${ }^{14}$ They are targeted because of such false beliefs and therefore discriminated against, which a situation which places their lives at risk.

This article discusses the nature of superstition and myths about PWA in Tanzania and how some societies have perpetrated discriminatory acts against PWAs as an outcome of these false beliefs. The paper discusses the ramifications of these in the context of the rights of PWA. The paper further explains the conflict between superstitions, harmful cultural beliefs and human rights. Various findings made from legal, medical and social perspectives that endeavor to illuminate the existence of PWA were consulted and referred to. It is submitted that there are deep-seated harmful cultural beliefs which seem to pose serious obstacles to the implementation of the law and the protection of the rights of PWA in Tanzania.

\subsection{What is superstition?}

In this article, superstition is construed to be

... an irrational belief that an object, action, or circumstance not logically related to a course of events influences its outcome, or a belief, practice, or

\footnotetext{
Schiappa Beyond Representational Correctness 5. Schiappa Beyond Representational Correctness 5. Schiappa Beyond Representational Correctness 5. Schiappa Beyond Representational Correctness 5. Schiappa Beyond Representational Correctness 5. Ntetema 2007 http://news.bbc.co.uk/2/hi/africa/7148673.stm. Ntetema 2007 http://news.bbc.co.uk/2/hi/africa/7148673.stm. Farmer 2004 Dev World Bioeth 17.
} 
rite irrationally maintained by ignorance of the laws of nature or by faith in magic or chance. ${ }^{15}$

Various superstitious practices suggest false explanations of natural events. Inquisitiveness about things that are hidden or are still in the future also plays a considerable part. For example, one can discern it in the various kinds of divination. With this in mind, superstitions may roughly be classified as cultural, personal or religious.

\subsection{What are harmful cultural beliefs?}

There is no universally and clear agreed definition of harmful cultural beliefs and practices. However, article 1(e) of the Disability Protocol defines "harmful practices" as including behaviour, attitudes and practices based on tradition, culture, religion, superstition or other factors which negatively affect the human rights and fundamental freedoms of persons with disabilities, or which perpetuate discrimination. ${ }^{16}$ Moreover, harmful cultural beliefs and practices are systems of thought that lead to specific valuebased discrimination against particular group of people, and they challenge the human rights of the people affected by them. ${ }^{17}$ For example, in many Africa societies and in Tanzania in particular people with albinism have been associated with witchcraft and it is believed that they are not human beings but rather that they are ghosts. Some believe that PWA are cursed, and that when their body parts are mixed with charms they can bring wealth and prosperity..$^{18}$ The killing of PWA is considered or presented by its perpetrators as part of accepted cultural practice. ${ }^{19}$ However, on the face of it this is in violation of their right to life. Article 11 of the Disability Protocol ${ }^{20}$ therefore obliges the state to take measures to eliminate harmful practices perpetrated on persons with disabilities, including witchcraft, abandonment, concealment, ritual killings or the association of disability with omens.

The authors of this paper is of the view that, despite the existence of harmful cultural beliefs and practices, there are many positive cultural beliefs and practices in communities, such as those offering social benefits

\footnotetext{
15 Wordnik 2012 https://www.wordnik.com/words/superstition.

16 Protocol to the African Charter on Human and Peoples' Rights on the Rights of Persons with Disabilities in Africa (2018) (Disability Protocol).

17 Kajiru Clash between Harmful Cultural Beliefs and Human Rights 102.

18 Kajiru Clash between Harmful Cultural Beliefs and Human Rights 102.

19 OHCHR date unknown https://www.ohchr.org/Documents/Publications/FactSheet23 en.pdf.

20 OHCHR date unknown https://www.ohchr.org/Documents/Publications/FactSheet23 en.pdf.
} 
and those promoting equality and social solidarity which therefore need to be protected when working to end harmful cultural beliefs and practices.

\subsection{What is Albinism?}

According to the National Organization for Albinism and Hypopigmentation, "albinism in humans is the absence of melanin or colour in any or all of the person's skin, hair and eyes." ${ }^{21}$ Albinism is said to be a world-wide genetic trait that affects all genders and races. ${ }^{22}$ It "results in the birth of a child whose appearance is markedly pale (mostly white) compared to both parents." 23

\section{The rights of persons with Albinism}

This part of the paper examines the numerous international conventions, regional treaties and national laws that protect PWA. Although most legal instruments do not specifically address issues of PWA, a broad and generous explanation of the provisions in these instruments can be used to protect the rights of PWA in Tanzania. The Tanzanian government has ratified most of the conventions that protect human rights and under article 26 of the Vienna Convention Tanzania is bound to adhere in good faith to the standards enshrined in the various international treaties by domesticating these treaties.

\subsection{The Universal Declaration of Human Rights (UDHR) $)^{24}$}

The UDHR is a source of what has been achieved for human rights at the international, regional, national, and local level. ${ }^{25}$ The development of mechanisms for the protection of human rights at the United Nations has been directly linked with the UDHR. ${ }^{26}$ The creation of a human rights culture in which everybody participates, beyond divisive ideologies, is the ultimate vision of the UDHR. ${ }^{27}$ The UDHR stipulates that all people in the world are entitled to all the rights and freedoms set forth in the declaration, without distinction of any kind. ${ }^{28}$ In a broad interpretation, the UDHR protects PWA as they form part of the human family and they are entitled to equal protection, among other entitlements. PWA have rights to life, dignity and freedom like any other person in society, as it is provided under article 1 of

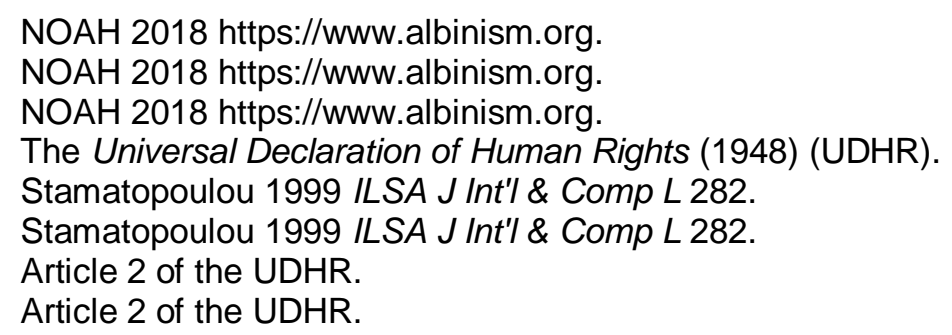


the UDHR that "all human beings are born free and equal in dignity and rights." Thus, the characterisation as PWA is not a ticket to justify violation and the infringement of their rights. Tanzania is bound to advocate, teach and educate its citizens about human rights issues and promote respect for the dignity of PWA.

\subsection{The International Covenant on Civil and Political Rights (ICCPR $)^{29}$}

The ICCPR provides for the protection of civil and political rights, and this paper finds that articles 6 and 7 of the ICCPR are relevant to the protection of the rights of persons with disabilities, including PWA. Article 6 provides for the right to life and article 7 provides for the right to freedom from torture, punishment and cruel or inhumane or degrading treatment. These rights may be violated when persons with disabilities are placed in inappropriate environments. This is to say, PWA rights may be violated when are exposed to conditions that put their lives in danger, thus violating their rights to life, freedom from discrimination and livelihoods, for instance. Obviously, the killing of PWA is a violation of the numerous rights guaranteed under the ICCPR.

\subsection{The International Covenant on Economic, Social and Cultural Rights (ICESCR) ${ }^{30}$}

The ICESCR states clearly in its preamble that the rights entrenched in it are derived from the inherent dignity of the human person. It is significant and indisputable that the preamble responds to the rights of persons with disabilities, including PWAs. Further, article 2(2) of the ICESCR provides that "the states parties to the present Covenant undertake to guarantee that the rights enunciated in the present Covenant will be exercised without discrimination of any kind as to race, colour, sex, language, religion, political or other opinion, national or social origin, property, birth or other status." Hence, the ICESCR generally ensures equality for PWA.

\subsection{The International Convention on the Elimination of All Forms of Racial Discrimination (ICERD) ${ }^{31}$ and the Convention on the}

\footnotetext{
29 The International Covenant on Civil and Political Rights (1966) (ICCPR).

30 The International Covenant on Economic, Social and Cultural Rights (1966) (ICESCR).

31 The International Convention on the Elimination of All Forms of Racial Discrimination (1965) (ICERD).
} 


\section{Elimination of All Forms of Discrimination against Women $\left(\right.$ CEDAW) ${ }^{32}$}

The ICERD and the CEDAW establish the principle of non-discrimination with respect to the enjoyment of all human rights for the categories of persons covered. Specifically, these conventions are of obvious importance in the context of discrimination against people and add to the general provisions against discrimination in the ICCPR and the ICESCR. PWA are specifically suffering in this respect, as they are being discriminated against because they are disabled, and they belong to the category which is regarded as a curse in most African societies. ${ }^{33}$

\subsection{The Convention on the Rights of Persons with Disabilities $(C R P D)^{34}$}

The CRPD promotes, protects and ensures the full and equal enjoyment of fundamental freedoms by all persons with disabilities, and respect for their inherent dignity. Article 1 of the CRPD includes all groups of people who have long-term disabilities, and prohibits the erection of any barrier that may hinder their full and effective participation in society on an equal basis with others. Article 10 insists that persons with disabilities have the right to enjoy life on an equal basis with others. This Article states that no one may deprive another person of the right to enjoy his/her life. So the humanity of PWA is fully acknowledged, regardless of the myths, in terms of their rights. PWA are human beings. The worst discrimination against PWA is their dehumanisation, which lays the foundation for horrifying physical attacks against them.

\subsection{African Charter on Human and Peoples' Rights (African Charter) ${ }^{35}$}

Article 2 of the African Charter states that "every individual shall be entitled to the enjoyment of the rights and freedoms recognised and guaranteed in the African Charter without distinction." According to the African Charter, "human beings are inviolable and ... every human being shall be entitled to respect for his life and the integrity of his person and no one may be arbitrarily deprived of this right." ${ }^{36}$ This is to the effect that persons with albinism cannot be devalued, and like any other persons, they have the right to enjoy life and live in peace without violence.

32 The Convention on the Elimination of All Forms of Discrimination against Women (1979).

33 Article 1 of the Convention on the Rights of Persons with Disabilities (2007) (CRPD).

34 The CRPD.

35 The African Charter on Human and Peoples' Rights (1981) (African Charter).

36

Article 4 the African Charter. 


\subsection{The Protocol to the African Charter on Human and Peoples' Rights on the Rights of Persons with Disabilities in Africa (Disability Protocol) $^{37}$}

The Disability Protocol provides that the rights and dignity of persons with disabilities should be promoted, protected and ensured in order to enable them to enjoy fully and equally all their human rights and fundamental freedoms. Article 2 of the Protocol requires States Parties to take appropriate and effective measures to ensure, protect and promote the rights and dignity of persons with disabilities, without discrimination on the basis of disability. Thus, the states are required to adopt appropriate measures for the implementation of the rights recognised in the present protocol. Thus, Tanzania is also bound to take all appropriate measures to ensure, promote and protect PWA's rights accordingly.

\subsection{The Constitution of the United Republic of Tanzania (CURT) ${ }^{38}$}

Apart from the international conventions, under article 13 the CURT guarantees equal rights to all persons. That being the case, PWA are not excluded. PWAs are human beings, are hence born free and are equal to other human beings, although these rights seem to be obscured in Tanzania due to the prevalent discrimination against PWA.

\subsection{The Persons with Disability Act (2010 Act) ${ }^{39}$}

Section 4(a) provides for respect for human dignity and an individual's freedom, and prohibits discrimination against PWD.40 This means that PWD are bound to enjoy their lives, and that in no circumstances are they to be discriminated against, excluded or restricted because of their disability, as that would affect, impair or nullify their recognition, enjoyment or exercise on an equal basis of their fundamental rights and freedoms.

In Tanzania, history has shown that tribes like the Mang'ati, Maasai and Wachagga are the leading culprits in spreading various myths against PWA. ${ }^{41}$ For example, it is alleged that a child who is born with albinism in these tribes is killed instantly at birth. ${ }^{42}$ To them a child with albinism is a

37 The Protocol to the African Charter on Human and Peoples' Rights on the Rights of Persons with Disabilities in Africa (2018) (Disability Protocol).

38 The Constitution of the United Republic of Tanzania, 1977 (as amended).

39 The Persons with Disability Act 9 of 2010 (2010 Act).

40 Section 4(a) of the 2010 Act.

41 Possi and Possi 2017 ADRY 120.

42 Possi and Possi 2017 ADRY 120. 
result of bewitchment in the family, or the child is a curse, or it is a punishment inflicted by an angry god for some wrongs done by the family. 43

\section{Prevailing myths, superstitions and harmful cultural beliefs pertaining to PWA in Tanzania}

The discussion below highlights several harmful culture beliefs, dangerous myths and superstitions that endanger the lives of PWA. Examples are the myth that albinism brings bad luck and that it is a curse, ${ }^{44}$ the result of witchcraft, a sign that the ancestors are unhappy, or evidence of the mother's infidelity. There is also the belief that the body parts of PWA can bring wealth and good luck when ground into witchcraft potions, that such people do not die but only disappear, and that PWA are not human beings but ghosts. ${ }^{45}$ Some societies also believe that albinism occurs when a pregnant woman scolds or laugh at someone living with albinism or when she has sexual interaction with a mzungu (i.e. a white man). ${ }^{46}$

\subsection{PWA: an international phenomenon}

Persons with albinism are found in all societies of the world and on all the continents - Europe, Africa, America and Asia. ${ }^{47} \mathrm{~A}$ report by the National Organization for Albinism and Hypopigmentation (NOAH) reveals that the prevalence of albinism varies across the world. ${ }^{48}$ The report suggests that in North America ${ }^{49}$ and Europe an estimated one in every 20,000 persons has some form of albinism. However, all over the world persons with albinism are continuously facing prejudiced perceptions based on their outward appearance. ${ }^{50}$ In many cultures persons with albinism are portrayed as possessing supernatural powers, and discrimination and bias against their appearance is to be found in art, films, and fiction. ${ }^{51}$ For example, Barker refers to the 1978 comic film Foul Play, directed by Colin Higgins, which presents an albino as a killer with a murderous character. ${ }^{52}$ Also the 2006 film The Da Vinci Code, directed by Ron Howard, which is

\footnotetext{
Possi and Possi 2017 ADRY 120.

Possi and Possi 2017 ADRY 120.

Possi and Possi 2017 ADRY 121.

Possi and Possi 2017 ADRY 120.

NOAH 2018 https://www.albinism.org.

NOAH 2018 https://www. albinism.org.

NOAH 2018 https://www. albinism.org.

Lipenga and Ngwira 2018 DGS 1472.

Possi and Possi 2017 ADRY 118.

Lipenga and Ngwira 2018 DGS 1472.
} 
based on a novel of the same name by Dan Brown, stereotypes an albino character as a unique and disturbing killer..$^{53}$

PWA are also found in other African countries such as Nigeria, South Africa, Namibia, Malawi and Zimbabwe, ${ }^{54}$ and the literature describes clear examples of discrimination and marginalisation aimed at them in these countries as well. ${ }^{55} \mathrm{It}$ is argued in the literature that what really differentiates them from one another is the treatment they receive, based on the perceptions of the societies in which they live. ${ }^{56}$ For example it has been reported that PWA are in distress because of the challenges they encounter in their daily lives. In Nigeria albinos have suffered untold derogatory insults. They are called various names depending on the tribes they belong to. Thus, the Yoruba call them Afin, which is [an] insult. The Igbo call them Ayarin, the Edo people call them Ebo or Akwa, the lbom people call them Bakara, while the Hausa call them Bature Ntuda. All of these names mean "fake white man". ${ }^{57}$

This derogatory term means "an albino Negro; a freak someone who is not up to the mark of normality". ${ }^{58}$ Under the Same Sun (UTSS) provides epidemiological data on albinism based on a public survey in African countries that was published by the World Health Organization (WHO) in 2006. This organisation mentions a prevalence of 1 in 100. The prevalence of PWA in South Africa is estimated at 1 in 11545 , in Zimbabwe at 1 in 6 531, in Tanzania at 1 in 270000 , and in Nigeria at 1 in $8267 .{ }^{59}$ With regard to the above estimates, one can argue that PWA are found not only in Tanzania but across Africa. In this context Tanzanian society therefore needs to understand that albinism is a worldwide genetic problem as it affects all people of all races across the world. ${ }^{60}$ Tanzanians have to understand that many people in the world are carriers of the recessive gene that causes albinism, and that it is a genetic condition which is a problem that is passed on from parents to children.

\subsection{Albinism is a curse}

In many diverse cultures in Africa there are various myths and beliefs that ascribe albinism to a curse by the gods or by dead ancestors. ${ }^{61}$ Some

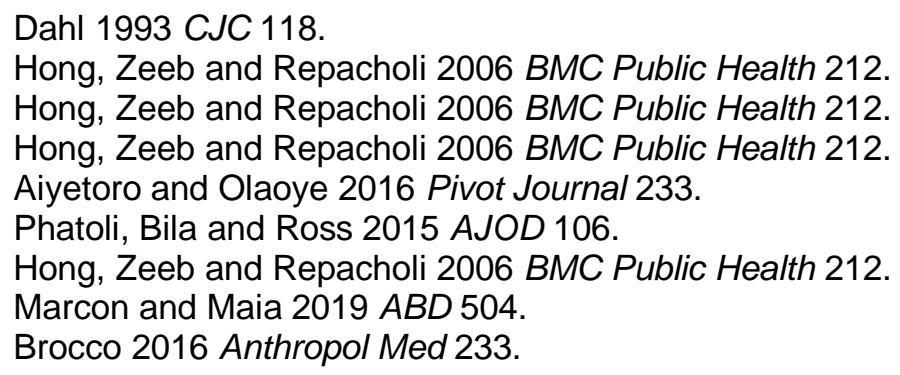


people even believe that contact with a PWA can result in bad luck, sickness, or even death. ${ }^{62}$ Moreover, in some societies giving birth to a baby with albinism is something that carries severe stigma. ${ }^{63}$

Myths and superstitions against PWA have led to discrimination, teasing and verbal abuse and, worst of all, killings. ${ }^{64}$ In many cases, and especially in rural villages, people with albinism are shut away and cut off from society. ${ }^{65}$ However, ostracising them from society is a violation of their rights, as stipulated under article 2 of the UDHR and other international conventions and national legislation. However, the parents or relatives choose to lock PWA indoors for their own safety and for "security purposes". Freedom of movement is stipulated under article 17 of the CURT and the equality of all people is also recognized, ${ }^{66}$ yet PWA seem to be excluded from these fundamental rights as their lives are constantly at risk.

In this regard, it is argued that it is the most important function of CURT is to uphold the equality of the rights of all Tanzanians. As the "mother law" in the country, CURT lists equality first in the order of rights to stress its importance. Moreover, it is also important to comply with the international instruments as provided for under article 26 of the Vienna Convention. From the legal point of view human rights, albinism must be considered as a disability instead of a curse. It has been pointed out that from a medical point of view albinism is only a condition of the human body which results in a distortion of skin pigmentation. ${ }^{67}$

\subsection{Albino body parts can bring a blessing or good luck}

The report by the Special Representative of the Secretary-General of the UN on violence against children with albinism indicates that "persons with albinism are perceived as a curse from the gods and a charm made from their body parts is considered to have magical powers that bring wealth, success and good luck."68 It is also believed that a person who drinks the blood of a person with albinism will receive magical powers. ${ }^{69}$ This ritual, which is associated with witchcraft, is said to be more powerful if the victim screams during the amputation, so body parts are often cut from live victims,

\footnotetext{
Braathen and Ingstad 2016 Disability and Society 599.

Masanja 2015 IJER 244.

Schühle Medicine Murder of People with Albinism 219.

Possi and Possi 2017 ADRY 123.

Article 12(2) of the CURT.

UTSS 2012 https://underthesamesun.com/sites/default/files/UTSS\%20report\%20 to\%20UN\%20-\%20REPORT.pdf.

68 ACPF 2014 https://violenceagainstchildren.un.org/sites/violenceagainstchildren.un. org/files/document_files/africanreport_on_violence_against_children2014.pdf. Kajiru Clash between Harmful Cultural Beliefs and Human Rights 123.
}

69 
especially children. ${ }^{70}$ It is revealed that in the context of harmful cultural beliefs witchdoctors have influenced the huge demand for PWA's body parts, resulting in the killing of these people in East Africa and Tanzania in particular. ${ }^{71}$

In most cases the perpetrators of the murder of PWA are predominantly witchdoctors. ${ }^{72}$ Witchdoctors are indirectly involved in the murder of PWA by simply directing those who come to see them to bring them the bodyparts and/or blood of PWA. ${ }^{73}$ In some cases witchdoctors allegedly advise their clients to drink the blood or consume the body parts in order to obtain wealth. ${ }^{74}$ Because society perceives PWA as "sacrificial lambs", people accept the advice without qualms. Tanzanian society believes in witchcraft to boost economic welfare, and therefore the incidence of the killing of PWA is clear evidence of the belief in witchcraft in Tanzania. ${ }^{75}$ Ritual killing in Tanzania, particularly for the purpose of economic gain and good luck, has a long history. ${ }^{76}$ Sanders recalls incidents in 1999 in the Mbeya region in southwest Tanzania where youths were reportedly killed and skinned. ${ }^{77}$ The killings reportedly occurred as a result of witchcraft activities. ${ }^{78}$ The skins of the victims were allegedly sold in countries such as Zambia, the Democratic Republic of Congo, and Malawi. ${ }^{79}$ Shockingly, similar incidents involving the killing of albinos were reported about ten years later both within and outside Tanzania. ${ }^{80}$

The selling of PWA's body parts has become a lucrative business, which makes it difficult to combat. ${ }^{81}$ This is because many people hold the belief that good luck can be obtained by wearing charms or ingesting potions procured from albino body parts. ${ }^{82}$ It was reported in 2016 that, as of October of that year, there had been more than 173 attacks in Tanzania, with 76 killings, 74 survivors, 1 abduction, and 22 grave violations of the rights of the victims. ${ }^{83}$ However, it is suggested that the number of attacks

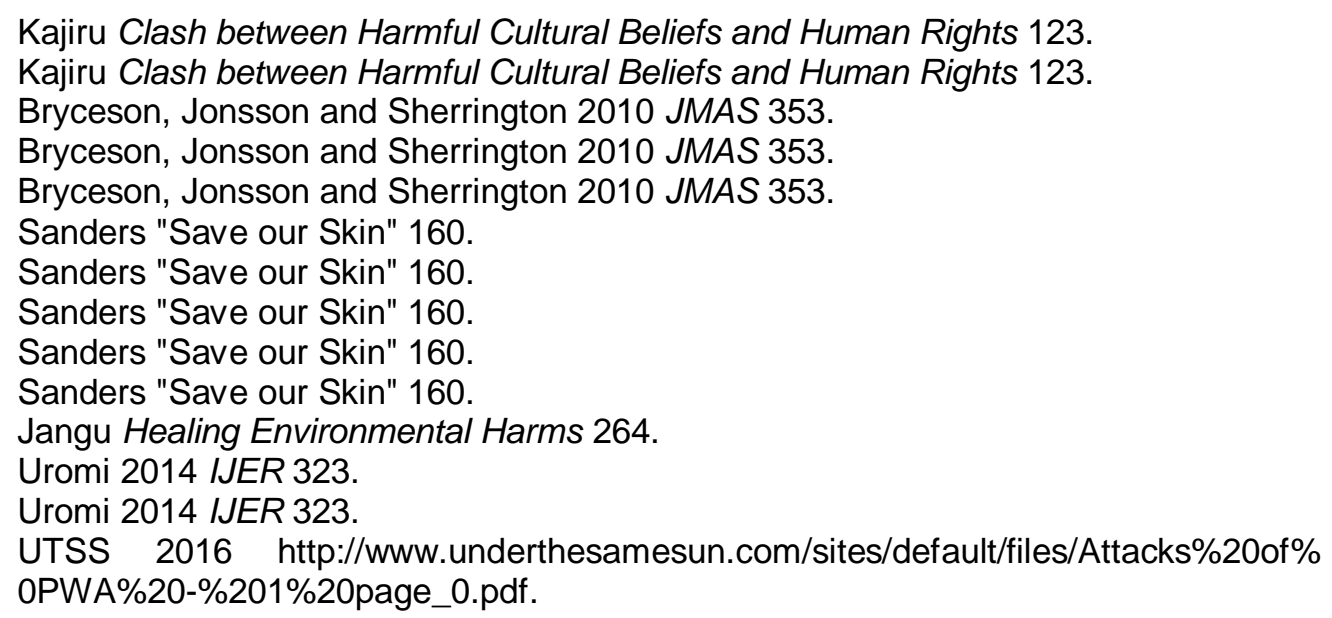


could be greater than the reported figures, particularly because the sources of such information are occluded by the secrecy inherent in witchcraft. ${ }^{84}$ The report also revealed that witchcraft-related crimes continue to be problematic because law enforcement structures often find it difficult to deal with cases of this nature. ${ }^{85}$ Owing to the secret nature of witchcraft-related rituals and the vulnerability and stigmatisation of the targeted population, it is believed that many attacks remain undocumented and unreported. ${ }^{86}$

Tragically, albinism has nothing to do with charms or good luck in a real life. ${ }^{87}$ Persons with albinism are just human beings like anyone else and do not possess any magical powers. ${ }^{88}$ Witchdoctors are trying to spread all these myths in order to enrich themselves at the expense of the lives of others. ${ }^{89} \mathrm{It}$ is absurd to think that a charm or potion concocted from the body parts of PWA has magical powers, or that they can bring success, wealth and good luck when consumed or worn.

\subsection{People with albinism never die}

In January 2006 the killing of PWA in Tanzania was drawn to public consciousness ${ }^{90}$ when it was reported that the number of outrageous killings of PWA had increased and that violations of the right to life had occurred through their torture during the practice of witchcraft. ${ }^{91}$ It was revealed that from 2006 to 2014 more than 74 PWA had been violently attacked..$^{92}$ Most of the killings and attacks had occurred in the lake regions, namely Mwanza, Shinyanga, Simiyu, Geita, Kagera, and Mara. ${ }^{93}$

On 31 January 2013 a 7-year-old boy with albinism was attacked while he was asleep. ${ }^{94}$ The attackers slashed his forehead, right arm and left shoulder, and chopped off his left arm above the elbow, using machetes. He did not survive the attack. ${ }^{95}$ His grandfather, a 95-year-old man, was

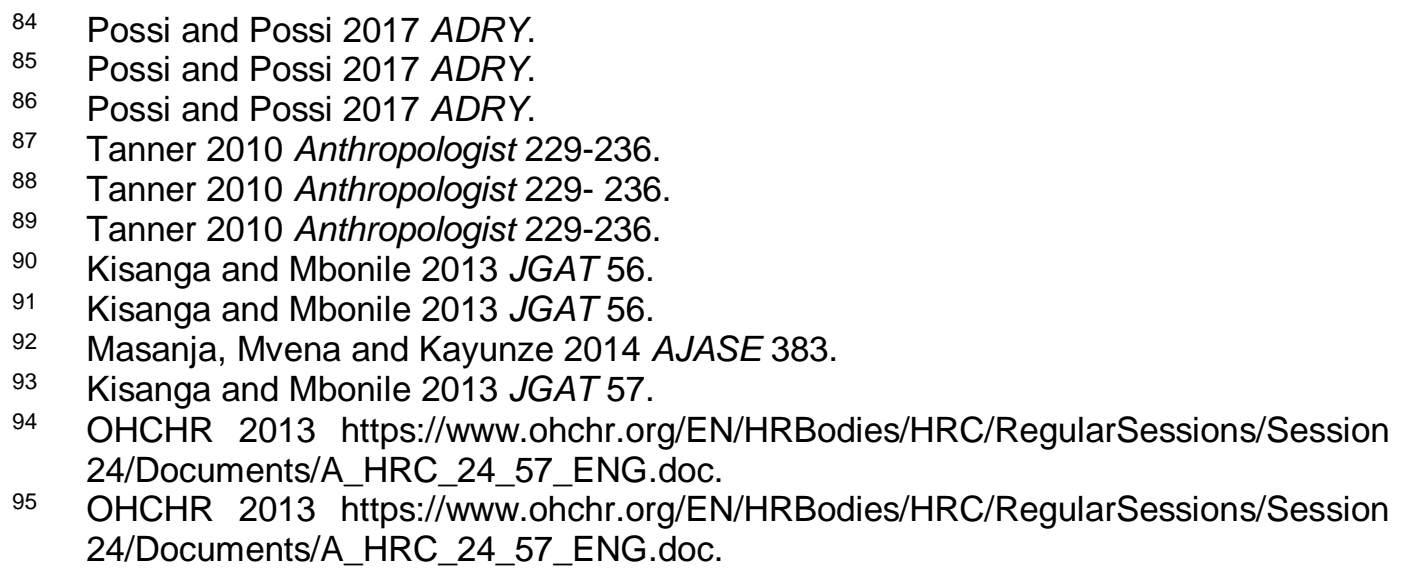

95 OHCHR 2013 https://www.ohchr.org/EN/HRBodies/HRC/RegularSessions/Session 24/Documents/A_HRC_24_57_ENG.doc. 
killed while trying to protect his grandson. ${ }^{96}$ The belief is that such senseless attacks are driven by greed and superstition rooted in harmful traditional cultural beliefs. ${ }^{97}$

According to a report by Under the Same Sun, the killing of a girl with albinism also took place on 17 February 2015 in the Geita region. In this incident both Yohana's arms and her legs were hacked off. This incident was followed by four more killings. On 7 March 2015 a six-year-old boy by the name of Baraka Cosmas was also killed in a witchcraft-related incident in Kipeta village in the Sumbawanga district; and on 14 May 2015 a 30-yearold woman known as Limi Luchoma was killed in the Katavi region. ${ }^{98}$ Recently, on 12 April 2020, PWA Josephat Torner, who was a great Tanzanian human rights activist and resident director of the Josephat Torner Foundation Europe (JTFE) died in a car accident. ${ }^{99}$ The above sources state that there is no doubt that a person with albinism dies like any other normal person. ${ }^{100}$ The prevailing myth that PWA simply vanish is therefore undeniably refuted by the above evidence as provided by the UTSS report.

\subsection{PWA are not human - they are ghosts}

Persons with albinism are often treated as misfits or outcasts. ${ }^{101}$ As "whiteskinned people in a black society, they are shunned and feared as the products of witchcraft, therefore [they are] treated as if they are out of the ordinary." 102 The idiosyncratic appearance of PWA happens to have a powerful impact on their lives from birth until death. ${ }^{103}$ The powerful effect of the negative perceptions and beliefs highlighted above also resonates in the mainly negative portrayal of albinism in popular culture, especially in the portrayal of PWA in film and fiction. ${ }^{104}$ This portrayal, referred to as the "evil albino bias", 105 perpetuates societal intolerance, stereotypes and discrimination against this group of vulnerable people by manipulating the attitudes and opinions of audiences. ${ }^{106}$ In this context Mswela argues that

\footnotetext{
96 OHCHR 2013 https://www.ohchr.org/EN/HRBodies/HRC/RegularSessions/Session 24/Documents/A_HRC_24_57_ENG.doc.

97 OHCHR 2013 https://www.ohchr.org/EN/HRBodies/HRC/RegularSessions/Session 24/Documents/A_HRC_24_57_ENG.doc.

98 Loitare Combating Witchcraft Based Violations 46.

99 Kennedy $2020 \mathrm{https} / / /$ allafrica.com/stories/202004150147.html.

100 Kennedy $2020 \mathrm{https} / / /$ allafrica.com/stories/202004150147.html.

101 Kadenge et al 2014 MJSS 1232.

102 Kadenge et al 2014 MJSS 1232.

103 Kadenge et al 2014 MJSS 1232.

104 Mswela 2013 Med Law 79.

105 Mswela 2013 Med Law 79.

106 Morley Television, Audiences and Cultural Studies.
} 
realistic attitudes and opinions change radically as a consequence of what is seen or heard. ${ }^{107}$ There is therefore no doubt that Tanzanian society has been living with the stories, myths and tales about PWA ever since the existence of the state. ${ }^{108}$ Stereotyping PWA has strengthened and led to the stigmatisation and discrimination that accompany albinism. ${ }^{109}$

In particular, the distinctive physical differences in the colour of the skin, eyes and hair of PWA are reasons why PWA are often isolated, discriminated against and rejected by society. Bullying, ridiculing, antagonism and rejection are common forms of abuse that PWA must endure. Most of the descriptive terms that are used to refer to persons with albinism are derogatory and demeaning; ${ }^{110}$ as such terms seem to suggest that PWAs are lesser beings. In Kiswahili, which is spoken by the vast majority of Tanzanians, the name for a person with albinism is "zeruzeru", meaning "ghost-like creature", while another term refers to an albino as "mzungu", meaning "white man". Recently PWAs have been associated with the infamous statement "zeruzeru ni dili", which means "an albino is a business deal". ${ }^{111}$ There is no denying that such virulent statements increase tensions among PWA and threaten their survival.

Generally, many African people believe that PWAs are ghosts from Europe who carry bad omens. ${ }^{112}$ Sadly, such superstitious beliefs and racial classifications endanger PWA lives. Thus, PWA suffer from a lack of positive social relationships, especially in terms of marriage, and are often denied the right to find a partner or have a family of their own. ${ }^{113}$ While people who have a normal skin find it quite easy to find partners, PWA are usually forced to remain single because no one wants them. ${ }^{114}$ Their families also often refuse to approve the relationships they forge. ${ }^{115}$ It is also revealed that PWA struggle to have relationships with other members of the societies in which they live. ${ }^{116}$ It is suggested that society is largely silent about the plight of PWA, and the media have been unable to find a way of referring PWA in ways that can bring to the fore their humanity rather than

\footnotetext{
107 Morley Television, Audiences and Cultural Studies.

108 Alum, Gomez and Ruiz 2009 https://www.yumpu.com/en/document /read/27534479/hocus-pocus-witchcraft-and-murder-under-the-same-.

109 Alum, Gomez and Ruiz 2009 https://www.yumpu.com/en/document /read/27534479/hocus-pocus-witchcraft-and-murder-under-the-same-.

110 Dave-Odigie 2010 PSJ 68, 75.

111 Dave-Odigie 2010 PSJ 68, 75.

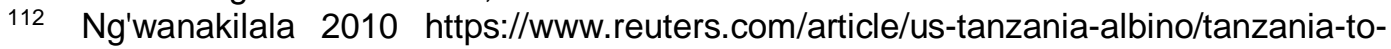
hang-blood-drinking-killer-of-albino-girl-idUSTRE66R3XP20100728.

113 LHRC Tanzania Human Rights Report.

114 LHRC Tanzania Human Rights Report.

115 LHRC Tanzania Human Rights Report.

116 LHRC Tanzania Human Rights Report.
} 
their genetic condition. It is true that, in the world where colour has defined so much of people's fate, from slavery to colonialism, PWA are in the unfortunate position of not having been born with any, or with very little, and thus remain eternal outsiders. ${ }^{117}$

The current situation of PWA in Tanzania contravenes their rights as stipulated in different treaties and national laws including the UDHR, as well as under the CRPD ${ }^{118}$, the African Charter ${ }^{119}$ and the CURT. ${ }^{120}$ The government is duty bound to protect its citizens against discrimination. When the government fails to discharge its constitutional duties, legal action may be taken against the government to secure those rights. Their pale skin and hair are a result of their limited melanin, which is responsible for colour in the hair and the skin. They are human beings like any other person and therefore they deserve respect and protection from all sorts of discrimination.

\subsection{Albinism is a contagious condition or disease}

It is believed that contact with PWA can cause diseases or illness. Some even go so far as to believe that even eating with, sitting next to, sleeping next to, and drinking from the same cup as a person with albinism will cause albinism, or you will smell like them or have a child with albinism. ${ }^{121}$ Many tribes in the Lake Victoria area in Tanzania, and especially the Wasukuma, believe that albinism is a disease or illness caused by the intervention of an agent such as another person, a witch, a sorcerer, a non-human, or a supernatural force. ${ }^{122}$

Witchcraft beliefs regarding PWAs have been sustained by witchdoctors for their own nefarious purposes and have caused severe misunderstanding among the population.

However, it is an unfounded belief that albinism is a communicable or contagious disease, as it is a genetic condition and is not contagious. ${ }^{123}$ Even blood transfusions do not transmit albinism, as it can be transmitted to another person only by genetic means, explicitly from parents to their children. ${ }^{124}$ Although all persons with albinism are to various degrees visually impaired, not all PWA are blind. However, they are very sensitive to

\footnotetext{
Ngugi 2010 http://allafrica.com/stories/201008210123.html.

Article 2 of CRPD.

Article 2 of the African Charter.

Article 13 of the CURT.

Kajiru Clash between Harmful Cultural Beliefs and Human Rights.

Kajiru Clash between Harmful Cultural Beliefs and Human Rights.

Kajiru Clash between Harmful Cultural Beliefs and Human Rights.

Kajiru Clash between Harmful Cultural Beliefs and Human Rights.
} 
light due to a lack of melanin. This requires the use of sunglasses to protect their eyes from the sun. ${ }^{125}$ However, regardless of their visual impairment, they can see during the day and at night, although they may be either shortor long-sighted and may need sight aids. Society needs to understand that PWA require basic support to protect them from the harmful ultraviolet radiation to which they are particularly vulnerable. Society also needs to understand that discrimination and neglect cause extreme pain, and that, due to their susceptibility to diseases such as skin cancer, they need love and care instead of rejection.

It is not true that people who share certain things with PWA will "catch" albinism. It is not a disease and it is not contagious. ${ }^{126}$ This misconception, coupled with a lack of education, is a key reason why the persecution of PWAs is prevalent. ${ }^{127}$ The lack of sufficient and sound knowledge about people with albinism means that folktales and superstition, and particularly practices that are fuelled by witchcraft, take the place of medical and scientific facts in the minds of many native Africans with and without albinism, which in turn has major effects on the social integration of PWA into Tanzanian society. ${ }^{128}$

\subsection{It is the mother's fault if a child has albinism}

Albinism is an inherited disorder that is already visible at childbirth. ${ }^{129}$ Children are in danger of being conceived with albinism if they have parents with albinism or parents who carry the gene for albinism. A deformity in one of several genes that produce or dispense melanin causes albinism. ${ }^{130}$ The deformity may bring about the absence of melanin generation or a diminished capacity for melanin creation. The defective genes are transmitted by both parents to the child and cause albinism. ${ }^{131}$ Albinism occurs in both males and females and is not specific to any race or ethnic group. However, lack of education and enough information about albinism are reasons why people discriminate against, kill and dismember PWA. ${ }^{132}$ Peter Ash, the founder of Under the Same Sun (UTSS), which is a charitable organisation working towards helping people with albinism, is quoted in the Epoch Times as saying: ${ }^{133}$

\footnotetext{
Kajiru Clash between Harmful Cultural Beliefs and Human Rights.

Possi and Possi 2017 ADRY.

Possi and Possi 2017 ADRY.

Possi and Possi 2017 ADRY.

Possi and Possi 2017 ADRY.

Lund and Gaigher 2002 Health Educ Res 365.

Lund and Gaigher 2002 Health Educ Res 365.

Lund and Gaigher 2002 Health Educ Res 365.

Lund and Gaigher 2002 Health Educ Res 365.
} 


\begin{abstract}
Without enough information on the condition, parents, families and communities have been at pains to explain the condition when a child with albinism is born. The idea behind it is that albinos look different, particularly in Africa because it's not a Caucasian country, and 95 per cent of children with albinism are born to parents who are both black. You can imagine if you're black and all of a sudden you have a child who's whiter than most Caucasians and you have no idea that it's a genetic disorder.
\end{abstract}

In most cases, it is the men who seem unable to accept their children who are born with albinism. ${ }^{134}$ This leaves women with the burden of raising these children alone. ${ }^{135}$ It has been reported in Tanzania, particularly in the lake area regions such as Mwanza, Shinyanga, Kahama and Simiyu, that many PWA are found and many women raise their children alone as their husbands abandon them. ${ }^{136}$ They either divorce their wives or simply leave to escape the stigma of having a child with albinism. Most children with albinism are raised by their grandmothers after their mothers have divorced and remarried. ${ }^{137}$ Furthermore, the United Nations High Commissioner for Human Rights has found that erroneous beliefs and myths are heavily influenced by superstition and put the security and lives of persons with albinism at constant risk. ${ }^{138}$ Killings and "attacks against [including mutilation] persons with albinism violate the right to life, the right to security of the person", and the prohibition of torture and ill-treatment - as enshrined in various international human rights treaties.

Society has to be educated to understand that it is not true that women are the source of albinism in children. ${ }^{139}$ Both parents, who may or may not be afflicted by albinism themselves, might carry the gene that is passed on to the child. ${ }^{140}$ Persons with albinism can give birth to normally pigmented children if their partners are not carriers of a similar recessive gene for albinism. ${ }^{141}$ The children may be carriers of the recessive gene but it will not be expressed in them. ${ }^{142}$ Statistics have shown that fifty per cent of PWA in Tanzania have a known albinistic relative, although very few understand or are educated about the medical and genetic causes of this condition. ${ }^{143}$ Many believe it is a punishment from God or bad luck, and that their "disease" could be contagious, which is often the view even of members of

\footnotetext{
134 Delaney 2008 https://www.theepochtimes.com/albinos-tanzania_1527998.html.

135 Possi and Possi 2017 ADRY.

136 Possi and Possi 2017 ADRY.

137 Brocco 2016 Anthropol Med 234.

138 Schühle Medicine Murder of People with Albinism 219.

139 Kajiru Clash between Harmful Cultural Beliefs and Human Rights.

140 Kajiru Clash between Harmful Cultural Beliefs and Human Rights.

141 Kajiru "Addressing Sexual Violence".

142 Kajiru "Addressing Sexual Violence".

143 Baker 2017 https://theconversation.com/the-trade-in-body-parts-of-people-withalbinism-is-driven-by-myth-and-international-inaction-84135.
} 
the medical and professional communities. ${ }^{144}$ However, the most accurate approach for diagnosis is through investigation of hereditary genes that are identified with albinism. ${ }^{145}$

\section{Conclusion}

Myths and superstition have a profound impact on the plight of PWA. This discussion has clearly illustrated how myths and superstitions underpin and exacerbate the prevailing ignorance in Tanzanian society of what albinism is. The unique condition that affects PWA makes them vulnerable to the violation of their human rights. They have been excluded and restricted based on their appearance, which exclusion has prevented their recognition as full members of the citizenry, despite the fact that international, regional and national laws guarantee the respect of all people's rights without discrimination.

Although law makers and enforcers, together with social and medical scientists, have taken initiatives and devised measures to address the powerful underlying assumptions that prevail in the minds of exploited members of superstitious societies, more must be done. Awareness, education and training must also be provided if substantive equality is to be achieved. Moreover, well-constructed laws and the advocacy of state policies are required in order to curb and eventually eradicate the practices that discriminate against PWA. It must be understood that all human beings are born free and equal in dignity and rights. They are endowed with reason and conscience and should act towards one another in a spirit of brotherhood. Discrimination against PWA because of their condition is contrary to their human rights. As a minority group among the diverse cultures in Tanzania, PWA need protection, and Tanzanian society needs to understand that albinism is neither more nor less than a genetic, biological affliction and that there is proof beyond reasonable doubt that there is nothing magical or supernatural about albinism. PWA are normal people who live and function just like other people.

Awareness campaigns are needed in order to make it possible to target and expose the myths surrounding albinism and ensure a full and immediate decline in the superstitious beliefs that lead to attacks on people with albinism. Educating the generality of the population would provide long-term and sustainable protection to people with albinism and address the root causes of the violence they experience.

\footnotetext{
144 Kajiru "Addressing Sexual Violence".

145 Kajiru "Addressing Sexual Violence".
} 


\section{Bibliography}

\section{Literature}

Agazue Role of Culture

Agazue C The Role of Culture of Superstitions in the Proliferation of Religiocommercial Pastors in Nigeria (AuthorHouse Bloomington 2013)

Aiyetoro and Olaoye 2016 Pivot Journal

Aiyetoro MB and Olaoye EO "Afro-Science Fiction: A Study of Nnedi Okorafor's What Sunny Saw in the Flames and Lagoon" 2016 Pivot Journal 226-246

Braathen and Ingstad 2016 Disability and Society

Braathen S and Ingstad B "Albinism in Malawi: Knowledge and Beliefs from an African Setting" 2016 Disability and Society 599-611

Brocco 2016 Anthropol Med

Brocco G "Albinism, Stigma, Subjectivity and Global-local Discourses in Tanzania" 2016 Anthropol Med 229-243

Bryceson, Jonsson and Sherrington 2010 JMAS

Bryceson D, Jonsson $\mathrm{J}$ and Sherrington $\mathrm{R}$ "Miners' Magic: Artisanal Mining, the Albino Fetish and Murder in Tanzania" 2010 JMAS 353-382

Dahl 1993 CJC

Dahl M "The Role of the Media in Promoting Images of Disability - Disability as Metaphor: The Evil Crip" 1993 CJC available at http://www.cjconline.ca/index.php/journal/article/view/718/624 accessed 20 October 2018

Dave-Odigie 2010 PSJ

Dave-Odigie CP "Albino Killings in Tanzania: Implications for Security" 2010 PSJ 68-75

Farmer 2004 Dev World Bioeth

Farmer P "Rethinking Medical Ethics: A View from Below" 2004 Dev World Bioeth 17-41

Hong, Zeeb and Repacholi 2006 BMC Public Health

Hong E, Zeeb H and Repacholi MH "Albinism in Africa as a Public Health Issue" 2006 BMC Public Health 212-217

Jangu Healing Environmental Harms

Jangu MH Healing Environmental Harms: Social Changes and Sukuma Traditional Medicine of Tanzania (PhD-dissertation University of Michigan 2012) 
Kadenge et al 2014 MJSS

Kadenge $\mathrm{M}$ et al "Anthroponyms of Albinos among the Shona People of Zimbabwe" 2014 MJSS 1230-1239

Kajiru "Addressing Sexual Violence"

Kajiru I "Addressing Sexual Violence against Women and Girls with Albinism in Tanzania: Legal Gaps and Social Challenges" in Addaney M (ed) Women and Minority Rights Law in Africa: Reimagining Equality and Addressing Discrimination (Eleven International Publishing The Hague 2019) 101-124

Kajiru Clash between Harmful Cultural Beliefs and Human Rights Kajiru I The Clash between Harmful Cultural Beliefs and Human Rights: A Case Study of Atrocities against People with Albinism in Tanzania (PhDthesis University of KwaZulu-Natal 2018)

Kisanga and Mbonile 2013 JGAT

Kisanga $\mathrm{P}$ and Mbonile MJ "Impact of Interventions of the Murder of People with Albinism in Lake Victoria: A Case of Shinyanga Region" 2013 JGAT 56-72

LHRC Tanzania Human Rights Report

Legal Human Rights Centre Tanzania Human Rights Report 2015 (LHRC Dar es Salaam 2016)

Lipenga and Ngwira 2018 DGS

Lipenga K and Ngwira E "'Black on the Inside': Albino Subjectivity in the African Novel" 2018 DGS 1472-1487

Loitare Combating Witchcraft Based Violations

Loitare E Combating Witchcraft Based Violations of the Rights to Life of Albinos in Tanzania; A Critique on the Law and Other Measures (LLMdissertation Mzumbe University 2016)

Lund and Gaigher 2002 Health Educ Res

Lund PM and Gaigher R "Health Intervention Programme for Children with Albinism at a Special School in South Africa" 2002 Health Educ Res 365372

Marcon and Maia $2019 A B D$

Marcon CR and Maia M "Albinism: Epidemiology, Genetics, Cutaneous Characterization, Psychosocial Factors" 2019 ABD 503-520

Masanja 2015 IJER

Masanja MM "'Albinos' Plight: Will Legal Methods be Powerful Enough to Eradicate Albinos' Scourge?" 2015 IJER 231-244 
Masanja, Mvena and Kayunze 2014 AJASE

Masanja MM, Mvena ZSK and Kayunze KA "Albinism: Awareness, Attitude and Level of Albinos' Predicament in Sukumaland, Tanzania" 2014 AJASE 382-395

Morley Television, Audiences and Cultural Studies

Morley D Television, Audiences and Cultural Studies (Routledge London 1992)

Mswela 2013 Med Law

Mswela MM "The Evil Albino Stereotype in Film: An Impediment to the Right to Equality" 2013 Med Law 79-93

Mulemi and Ndolo Albinism, Witchcraft, and Superstition in East Africa Mulemi BA and Ndolo UM Albinism, Witchcraft, and Superstition in East Africa: Exploration of Bio-cultural Exclusion and Livelihood Vulnerability (Catholic University of Eastern Africa Nairobi 2014)

Possi and Possi 2017 ADRY

Possi A and Possi A "The Identity Question versus Appropriateness of Legal Anti- discrimination Measures: Endorsing the Disability Rights Approach to Albinism" 2017 ADRY118-140

Sanders "Save our Skin"

Sanders T "Save our Skin: Structural Adjustment, Morality and the Occult in Tanzania" in Moore HL and Sanders T (eds) Magical Interpretations, Material Realities: Modernity, Witchcraft and the Occult in Postcolonial Africa (Routledge London 2003) 160-180

Schiappa Beyond Representational Correctness

Schiappa E Beyond Representational Correctness: Rethinking Criticism of Popular Media (State University of New York Press New York 2008)

Schühle Medicine Murder of People with Albinism

Schühle J Medicine Murder of People with Albinism in Tanzania - How Casino Capitalism Creates Rumourscapes and Occult Economies (Center for Area Studies, Freie Universität Berlin 2013)

Stamatopoulou 1999 ILSA J Int'l \& Comp L

Stamatopoulou $E$ "The Importance of the Universal Declaration of Human Rights in the Past and Future of the United Nation's Human Rights Efforts" 1999 ILSA J Int'l \& Comp L 281-289

Tanner 2010 Anthropologist

Tanner R "Ideology and the Killing of Albinos in Tanzania: A Study in Cultural Relativities" 2010 Anthropologist 229-236 
Uromi 2014 IJER

Uromi SM "Violence against Persons with Albinism and Older Women: Tackling Witchcraft Accusations in Tanzania" 2014 IJER 323-338

\section{Legislation}

Constitution of the United Republic of Tanzania, 1977 (as amended)

Persons with Disability Act 9 of 2010

\section{International instruments}

African Charter on Human and Peoples' Rights (1981)

Convention on the Elimination of All Forms of Discrimination against Women (1979)

Convention on the Rights of Persons with Disabilities (2007)

International Convention on the Elimination of All Forms of Racial Discrimination (1965)

International Covenant on Civil and Political Rights (1966)

International Covenant on Economic, Social and Cultural Rights (1966)

Protocol to the African Charter on Human and Peoples' Rights on the Rights of Persons with Disabilities in Africa (2018)

Universal Declaration of Human Rights (1948)

Vienna Convention on the Law of Treaties (1969)

\section{Internet sources}

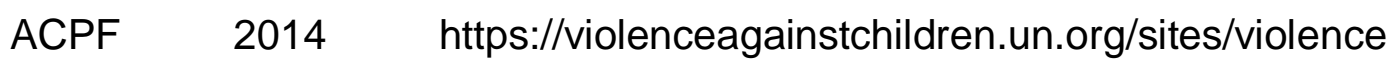
againstchildren.un.org/files/document_files/africanreport_on_violence_aga inst_children2014.pdf

African Child Policy Forum 2014 The African Report on Violence against Children

https://violenceagainstchildren.un.org/sites/violenceagainstchildren.un.org/ files/document_files/africanreport_on_violence_against_children2014.pdf accessed 2 August 2020

Alum, Gomez and Ruiz 2009 https://www.yumpu.com/en/document /read/27534479/hocus-pocus-witchcraft-and-murder-under-the-sameAlum A, Gomez M and Ruiz E 2009 Hocus Pocus, Witchcraft and Murder: The Plight of Tanzanian Albinos https://www.yumpu.com/en/document 
read/27534479/hocus-pocus-witchcraft-and-murder-under-the-sameaccessed 27 October 2018

Baker 2017 https://theconversation.com/the-trade-in-body-parts-of-peoplewith-albinism-is-driven-by-myth-and-international-inaction-84135

Baker C 2017 The Trade in Body Parts of People with Albinism is driven by Myth and International Inaction https://theconversation.com/the-trade-inbody-parts-of-people-with-albinism-is-driven-by-myth-and-internationalinaction-84135 accessed 27 October 2018

Delaney 2008 https://www.theepochtimes.com/albinos-tanzania_1527998. html

Delaney J 2008 Albinos under Siege in Tanzania https://www.theepochtimes.com/albinos-tanzania_1527998.html accessed on 20 April 2018

Kennedy 2020 https://allafrica.com/stories/202004150147.html

Kennedy N 2020 Activist Killed in Road Accident in Mwanza City https://allafrica.com/stories/202004150147.html accessed 6 May 2020

Ngugi 2010 http://allafrica.com/stories/201008210123.html

Ngugi M 2010 They Call us 'Albinos' - the Licence to Mock and Murder Fellow Humans http://allafrica.com/stories/201008210123.html accessed 20 April 2018

Ng'wanakilala 2010 https://www.reuters.com/article/us-tanzania-albino/ tanzania-to-hang-blood-drinking-killer-of-albino-girl-

idUSTRE66R3XP20100728

Ng'wanakilala F 2010 Tanzania to Hang Blood-drinking Killer of Albino Girl https://www.reuters.com/article/us-tanzania-albino/tanzania-to-hang-blooddrinking-killer-of-albino-girl-idUSTRE66R3XP20100728 accessed 17 August 2018

NOAH 2018 https://www.albinism.org/

National Organization for Albinism and Hypopigmentation 2018 Home Page https://www.albinism.org/ accessed 17 August 2018

Ntetema 2007 http://news.bbc.co.uk/2/hi/africa/7148673.stm

Ntetema V 2007 Tanzania Fear over Albino Killing http://news.bbc.co.uk/2/hi/africa/7148673.stm accessed 11 September 2018

OHCHR date unknown https://www.ohchr.org/Documents/Publications/

FactSheet23en.pdf 
Office of the United Nations High Commissioner for Human Rights date unknown Fact Sheet No 23: Harmful Traditional Practices Affecting the Health of Women and Children https://www.ohchr.org/Documents/ Publications/FactSheet23en.pdf accessed 30 October 2018

OHCHR 2013 https://www.ohchr.org/EN/HRBodies/HRC/RegularSessions/ Session24/Documents/A_HRC_24_57_ENG.doc

Office of the United Nations High Commissioner for Human Rights 2013 Report on Persons with Albinism https://www.ohchr.org/EN/HRBodies/ HRC/RegularSessions/Session24/Documents/A_HRC_24_57_ENG.doc accessed 2 April 2018

OHCHR $2019 \quad$ https://uganda.ohchr.org/Content/publications/ Albinism_Analysis_Report_2019.pdf

Office of the United Nations High Commissioner for Human Rights 2019 Enhancing Equality and Countering Discrimination against Persons with Albinism in Uganda https://uganda.ohchr.org/Content/ publications/Albinism_Analysis_Report_2019.pdf accessed 25 July 2020

UTSS 2012 https://underthesamesun.com/sites/default/files/UTSS\% 20report\%20to\%20UN\%20-\%20REPORT.pdf

Under the Same Sun 2012 Children with Albinism in Africa: Murder Mutilation and Violence - A Report on Tanzania with Parallel References to Other Parts of Sub-Saharan Africa https://underthesamesun.com/ sites/default/files/UTSS\%20report\%20to\%20UN\%20-\%20REPORT.pdf accessed 2 August 2020

UTSS 2016 http://www.underthesamesun.com/sites/default/files/ Attacks\%20of\%20PWA\%20-\%201\%20page_0.pdf

Under the Same Sun 2016 Reported Attacks of Persons with Albinism (PWA)

http://www.underthesamesun.com/sites/default/files/Attacks\%20of\%20PW A\%20-\%201\%20page_0.pdf accessed 24 July 2020

Wordnik 2012 https://www.wordnik.com/words/superstition Wordnik 2012 Superstition https://www.wordnik.com/words/superstition accessed 3 September 2018

\section{List of Abbreviations}

$A B D$

ACPF

ADRY
Anais Brasileiros de Dermatologicia

African Child Policy Forum

African Disability Rights Yearbook 


\begin{tabular}{|c|c|}
\hline AJASE & $\begin{array}{l}\text { Asian Journal of Applied Science and } \\
\text { Engineering }\end{array}$ \\
\hline Antropol Med & Anthropology and Medicine \\
\hline BMC Public Health & BioMed Central Public Health \\
\hline CEDAW & $\begin{array}{l}\text { Convention on the Elimination of All Forms of } \\
\text { Discrimination Against Women }\end{array}$ \\
\hline CJC & Canadian Journal of Communication \\
\hline CRPD & $\begin{array}{l}\text { Convention on the Rights of Persons with } \\
\text { Disabilities }\end{array}$ \\
\hline Cult Health Sex & Culture, Health and Sexuality \\
\hline CURT & $\begin{array}{l}\text { Constitution of the United Republic of } \\
\text { Tanzania }\end{array}$ \\
\hline DGS & Disability and the Global South \\
\hline Dev World Bioeth & Developing World Bioethics \\
\hline Health Educ Res & Health Education Research \\
\hline HPD & Health Policy and Development \\
\hline ICCPR & $\begin{array}{l}\text { International Covenant on Civil and Political } \\
\text { Rights }\end{array}$ \\
\hline ICERD & $\begin{array}{l}\text { Convention on the Elimination of All Forms of } \\
\text { Racial Discrimination }\end{array}$ \\
\hline ICESCR & $\begin{array}{l}\text { International Covenant on Economic, Social } \\
\text { and Cultural Rights }\end{array}$ \\
\hline IJER & $\begin{array}{l}\text { International Journal of Education and } \\
\text { Research }\end{array}$ \\
\hline ILSA J Int'I \& Comp L & $\begin{array}{l}\text { ILSA Journal of International and } \\
\text { Comparative Law }\end{array}$ \\
\hline JGAT & $\begin{array}{l}\text { Journal of the Geographical Association of } \\
\text { Tanzania }\end{array}$ \\
\hline JMAS & Journal of Modern African Studies \\
\hline LHRC & Legal and Human Rights Centre \\
\hline MJSS & Mediterranean Journal of Social Sciences \\
\hline Med Law & Medicine and Law \\
\hline $\mathrm{NOAH}$ & $\begin{array}{l}\text { National Organization for Albinism and } \\
\text { Hypopigmentation }\end{array}$ \\
\hline $\mathrm{OHCHR}$ & $\begin{array}{l}\text { Office of the United Nations High } \\
\text { Commissioner for Human Rights }\end{array}$ \\
\hline PSJ & Peace Studies Journal \\
\hline PWA & Persons with Albinism \\
\hline PWD & Persons with Disabilities \\
\hline UDHR & Universal Declaration of Human Rights \\
\hline
\end{tabular}


UN

United Nations

UTSS

Under the Same Sun

WHO

World Health Organization 